\title{
COVID-19 infodemic and Indonesian emotional and mental
} health state

\author{
Rizma Adlia Syakurah ${ }^{1}$, Violantina Linardi ${ }^{2}$, Ilsyafitri Bonita ${ }^{3}$ \\ ${ }^{1}$ Public Health Faculty, Sriwijaya University, Palembang, Indonesia \\ ${ }^{2,3}$ Faculty of Medicine, Sriwijaya University, Palembang, Indonesia
}

\begin{tabular}{|c|c|}
\hline Article Info & ABSTRACT \\
\hline Article history: & The currently ongoing coronavirus disease 2019 (COVID-19) pandemic \\
\hline Received Mar 30, 2021 & induced built-up fear and anxiety notably with non-stop surge information \\
\hline Revised Aug 22, 2021 & during this state is urgently needed for further intervention. This study aimed \\
\hline Accepted Sep 3, 2021 & $\begin{array}{l}\text { to identify the current pattern of depression, anxiety, stress and, emotional } \\
\text { disorder presented in the society and the association between Indonesian }\end{array}$ \\
\hline Keywords: & $\begin{array}{l}\text { news-seeking behaviour and their mental health state during the COVID-19 } \\
\text { outbreak. A cross-sectional study with } 1,508 \text { respondents was carried out }\end{array}$ \\
\hline COVID-19 & with online questionnaire consisted of depression, anxiety, and stress \\
\hline News dissemination & scale (DASS) and SRQ-20 as assessment tools that was distributed through \\
\hline Emotional & social media platforms from April 2-June 8, 2020. Data was analyzed using \\
\hline Mental health & $\begin{array}{l}\text { Mann Whitney, Kruskal Wallis, Post Hoc with Bonferroni, and Chi-square } \\
\text { test ( }<<0.05) \text {. As much as } 20.7 \% \text { of respondents were depressed, } 36.9 \% \text { had } \\
\text { anxiety, } 25.5 \% \text { had been stress, and } 27.6 \% \text { had emotional disorder. Most } \\
\text { respondents actively searched about COVID-19 especially through television } \\
\text { and social media platforms such as Twitter, Facebook, and Instagram. Type } \\
\text { of news and level of trust in COVID- } 19 \text { news were the factors that influenced } \\
\text { emotional and mental health state }(\mathrm{p}=<0.05 \text { ). Providing mental health } \\
\text { support in a timely and appropriate manner through a hotline team, media, or } \\
\text { multidisciplinary team, including mental health professional is an important } \\
\text { thing that the Indonesian government must do to help the Indonesian people } \\
\text { through this pandemic. }\end{array}$ \\
\hline
\end{tabular}

This is an open access article under the CC BY-SA license.

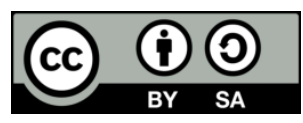

Corresponding Author:

Rizma Adlia Syakurah

Public Health Faculty

Sriwijaya University

J1. Raya Palembang-Prabumulih KM. 32 Indralaya, Ogan Ilir, South Sumatra 30662, Indonesia

Email: rizma.syakurah@gmail.com

\section{INTRODUCTION}

Coronavirus disease 2019 (COVID-19), caused by novel coronavirus, is an emerging respiratory disease and is considered a worldwide threat. This highly infectious disease was first reported in December 2019 in Wuhan (China) with its main clinical symptoms of fever, dry cough, fatigue, myalgia, and dyspnea [1], [2]. As of $6^{\text {th }}$ June 2020, World Health Organization (WHO) has shown that overall global case fatality rate of COVID-19 is 5.9\% [3], [4]. Ministry of Health in Indonesia stated that 29,521 people was tested positive for COVID-19 where 9,443 people have recovered and 1,770 people have died with $6.0 \%$ case fatality rate [5]. 
WHO has stated that since the onset of the epidemic outbreak, it is necessary to engage the community through radio-based activities and seek cooperation in order to ensure that the population is prepared to take precautions at individual level [6]. The term 'infodemic' was used by WHO to describe COVID-19 along with its escorting news as well as ambient hoax [7]. Due to massive circulating news, people are becoming more alert and eager to find the latest news from various platforms.

The advancing COVID-19 pandemic is raising concern and understanding emotional and mental health status is urgently needed in the society [8]. Preceding research had revealed a profound and wide range of psychosocial impacts on individuals, community, and international levels during outbreaks of infection. On an individual level, people are likely to experience fear of being sick, dying or helpless [9]. Around 10$30 \%$ of the societies were very or fairly worried about the possibility of being in contact with the virus. With the closure of schools and business, individuals experienced complex negative emotions [10], [11]. From the past 2 pandemics that were also caused by the coronavirus, many studies that investigated the psychological impact on the non-infected community revealed significant psychiatric morbidities which were found to be associated with younger age and increased self-blame [12]. If those reactions cannot be relieved in time, they are likely to lead to further irrational and violent behaviours.

Currently, there is no known information on the emotional and mental health of the society during the COVID-19 pandemic in Indonesia. A high level of awareness and curiosity about the COVID-19 latest news and its impact on emotional and mental health status were the interest of this research. This study aimed to identify the current pattern of depression, anxiety, stress and emotional disorder presented in society and the association between Indonesian news-seeking behaviour and their mental health state during the COVID19 outbreak. This may assist government agencies and healthcare professionals in safeguarding the psychological wellbeing of the community to face COVID-19 epidemic expansion in Indonesia.

\section{RESEARCH METHOD}

An observational analytic study with a cross-sectional approach was designed for the present study. The population is Indonesian internet users with 1,508 participants who responded to online questionnaires distributed through social media platforms on April 2-25, 2020. The depression, anxiety, and stress scale (DASS) questionnaire is a self-report measurement tool that measures depression, anxiety, and stress. DASS42 consists of 42 questions about symptoms of negative emotions in which the individual assesses the presence or absence of these symptoms in the past week. The DASS-42 questionnaire in this study has been translated into Bahasa Indonesia and has excellent value in both validity and reliability test which is 0.499 0.813 and 0.90 succesively. By using this questionnaire, participants were given a choice of 0-3 score to answer which will then be calculated and interpreted as 'depression' and 'no depression', 'anxiety' and 'no anxiety', and 'stress' and 'no stress'. Respondents were categorized as depression, anxiety, and stress for scores above 9,7 , and 14 consecutively.

Self-reporting questionnaire (SRQ) developed by WHO was used in this study as an emotional disability measurement tool to only screen for mental-emotional disorders. The SRQ questionnaire in this study has been translated into Bahasa Indonesia by the Indonesian Ministry of Health in the study of Idaiani et al. in 2009 [13]. The questionnaire was tested for validity by Ganihartono with a score of 0.88 . The SRQ questionnaire consisted of 20 questions raised on neurosis problems consisting of depression, anxiety, somatic, cognitive, and energy reduction with a 'yes' score for 1 question worth 1 point. The cutoff value that has been determined in this questionnaire is 6, which is considered an emotional disability [14].

Data were collected through interview using a closed-question questionnaire and one open-question. Then it proceeded to the process of checking/validating data, coding, recapitulation, tabulation, and statistically analyzed using the IBM SPSS Statistics 24 program. Bivariate data analysis was used in this study to analyze the relationship of Indonesian news-seeking behavior to the psychological and emotional impact of COVID-19 with Mann Whitney, Kruskal Wallis, Post Hoc with Bonferroni, and Chi-square test $(\mathrm{p}<0.05)$.

This research was approved by Mohammad Hoesin Central General Hospital and Faculty of Medicine Sriwijaya University Health Research Review Committee (IRB No.141/kepkrsmhfkunsri/2020). All respondents were informed of the study and provided consent before enrolling. Attribute codes were given to the participants to maintain anonymity.

\section{RESULTS AND DISCUSSION}

In this study, out of 1,508 respondents, $20.7 \%$ were depressed, $36.9 \%$ had anxiety, $25.5 \%$ had been stress, and $27.6 \%$ had an emotional disorder as shown in Figures 1 and 2. The socio demographic characteristics of respodents towards mental health states are shown in Table 1. Table 1 shows that almost all sociodemography factors have a significant relationship with depression, anxiety, and emotional disorder on 
participants ( $\mathrm{p}$-value $<0.05$ ). Post hoc Bonferroni analysis showed that the average total score among depression was greater in female vs male $(2,378)$, single vs married $(2,378)$, Senior high school vs Master degree $(3,196)$, student vs entrepreneur (3,704), non-health vs health background (798.8), and monthly expense $<1,000,000$ vs $>10,000,000$ (3,719). While, the anxiety, stress, and emotional disorders were greater in female vs male $(780.7$ for anxiety; 774.9 for stress; 677.4 for emotional disorders), single vs married (2,244 for anxiety, 2,457 for stress; 1,291 for emotional disorders), senior high school vs master degree (2,802 for anxiety, 3,355 for stress; 2,157 for emotional disorders), non-health vs health background (806.9 for anxiety; 801.1 for stress; 706.4 for emotional disorders), and monthly expense <1,000,000 vs >10,000,000 (2,992 for anxiety; 3,402 for stress; 2,517 for emotional disorders), and there is no difference among occupation group. The news dissemination of COVID-19 on Indonesian emotional and mental health state is shown in Table 2.

Table 1. Sociodemographic characteristics of respondents $(n=1,508)$

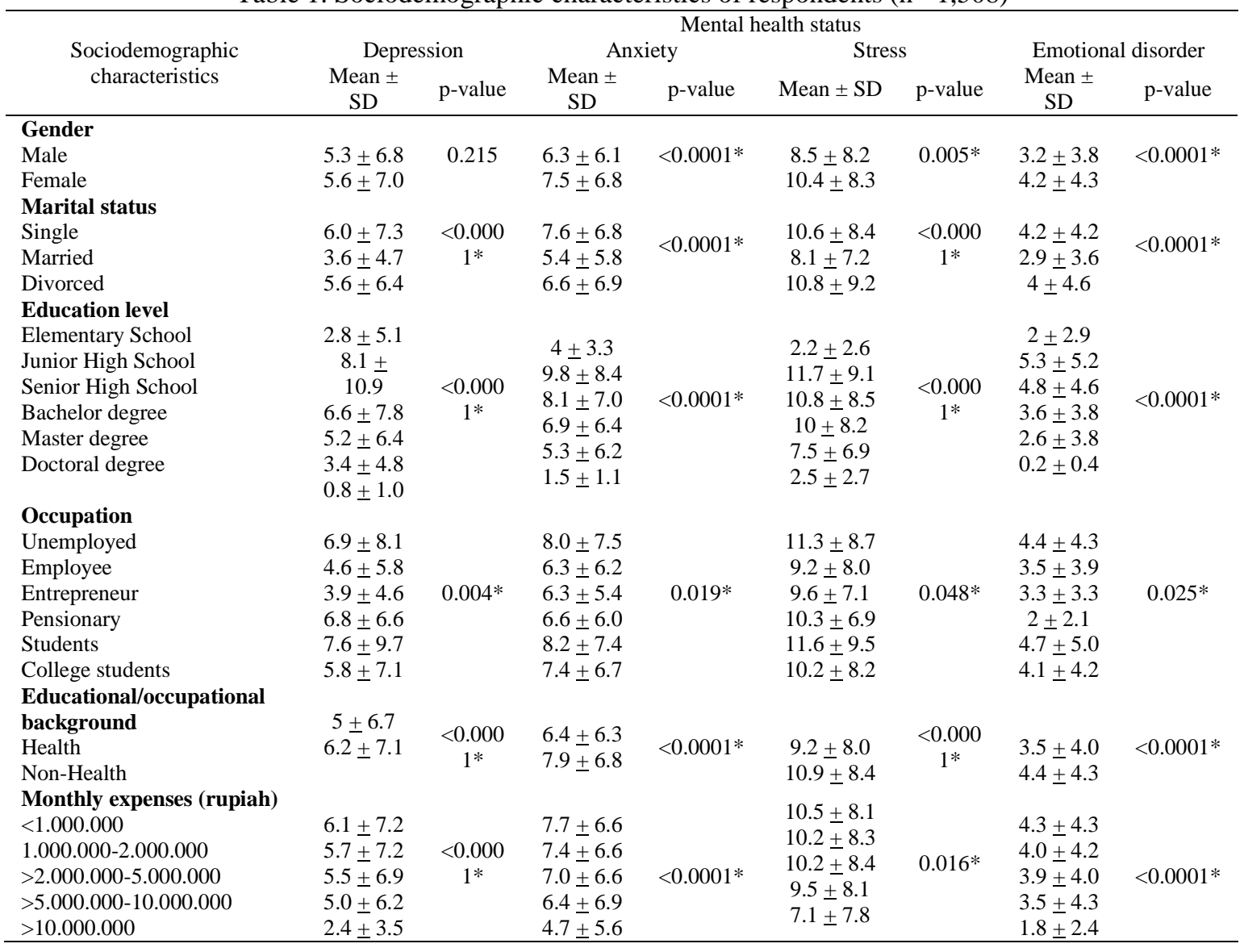

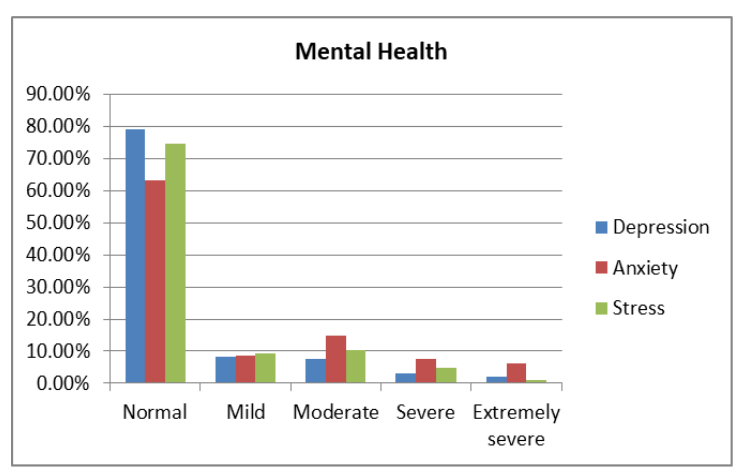

Figure 1. Prevalence of mental health state $(n=1,508)$

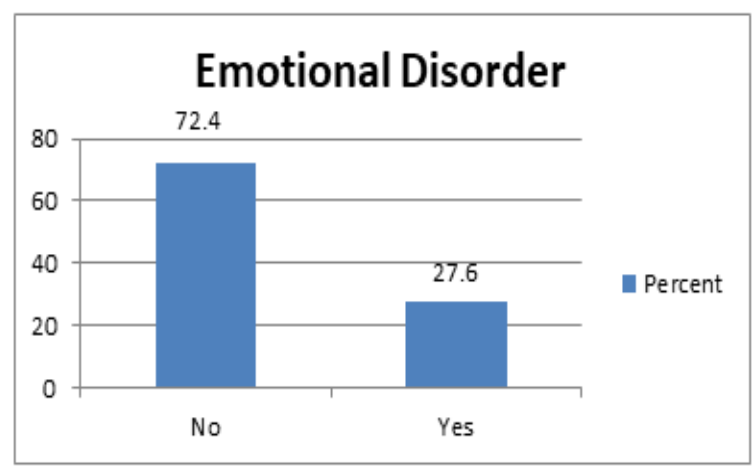

Figure 2. Prevalence of emotional disorder $(n=1,508)$ 
Table 2. The news dissemination of COVID-19 and mental health state $(n=1,508)$

\begin{tabular}{|c|c|c|c|c|c|c|c|c|}
\hline \multirow{3}{*}{$\begin{array}{l}\text { News dissemination } \\
\text { Update on the latest news }\end{array}$} & \multicolumn{8}{|c|}{ Mental health status } \\
\hline & \multicolumn{2}{|c|}{$\begin{array}{l}\text { Depression } \\
\text { (n, p-value) }\end{array}$} & \multicolumn{2}{|c|}{$\begin{array}{c}\text { Anxiety } \\
(\mathrm{n}, \mathrm{p} \text {-value })\end{array}$} & \multicolumn{2}{|c|}{$\begin{array}{c}\text { Stress } \\
(\mathrm{n}, \mathrm{p}-\mathrm{value})\end{array}$} & \multicolumn{2}{|c|}{$\begin{array}{c}\text { Emotional disorder } \\
\text { (n, p-value })\end{array}$} \\
\hline & & & & & & & & \\
\hline Yes & 289 & $0.000 *$ & 523 & $0.002^{*}$ & 361 & $0.008 *$ & 391 & $0.011 *$ \\
\hline No & 24 & & 33 & & 24 & & 25 & \\
\hline \multicolumn{9}{|l|}{ Sources } \\
\hline Television $(\mathrm{n}=1,012)$ & 187 & $0.020 *$ & 355 & $0.045^{*}$ & 243 & 0.062 & 260 & $0.022 *$ \\
\hline Online news $(\mathrm{n}=1,093)$ & 224 & 0.737 & 405 & 0.857 & 279 & 0.995 & 305 & 0.700 \\
\hline Facebook $(n=218)$ & 38 & 0.223 & 67 & $0.042^{*}$ & 42 & $0.027 *$ & 61 & 0.953 \\
\hline Whatsapp group $(n=606)$ & 116 & 0.229 & 217 & 0.518 & 160 & 0.564 & 156 & 0.210 \\
\hline Twitter $(n=396)$ & 111 & $0.000 *$ & 175 & $0.001 *$ & 128 & $0.000 *$ & 144 & $0.000^{*}$ \\
\hline Instagram $(\mathrm{n}=870)$ & 179 & 0.839 & 339 & $0.049^{*}$ & 247 & $0.004 *$ & 252 & 0.180 \\
\hline Youtube $(n=438)$ & 83 & 0.300 & 156 & 0.557 & 113 & 0.930 & 119 & 0.866 \\
\hline Line $(n=513)$ & 95 & 0.141 & 184 & 0.601 & 130 & 0.953 & 136 & 0.542 \\
\hline Radio $(n=60)$ & 7 & 0.108 & 19 & 0.474 & 11 & 0.249 & 9 & $0.038^{*}$ \\
\hline Friends/family $(\mathrm{n}=643)$ & 132 & 0.902 & 241 & 0.712 & 181 & $0.045^{*}$ & 178 & 0.989 \\
\hline Others $(n=8)$ & 3 & 0.374 & 3 & 0.970 & 1 & 0.972 & 2 & 0.868 \\
\hline \multicolumn{9}{|l|}{ Type of news } \\
\hline New cases $(n=957)$ & 262 & 0.680 & 465 & 0.463 & 321 & 0.485 & 347 & 0.472 \\
\hline Mortality rate $(\mathrm{n}=1,042)$ & 234 & 0.459 & 411 & 0.554 & 294 & 0.092 & 303 & 0.954 \\
\hline Recovery cases $(n=1,031)$ & 218 & 0.722 & 394 & 0.922 & 266 & 0.484 & 288 & 0.503 \\
\hline Preventive measures $(n=543)$ & 165 & $0.019 *$ & 305 & $0.024 *$ & 206 & $0.020 *$ & 212 & $0.000^{*}$ \\
\hline Donation $(n=342)$ & 97 & 0.708 & 180 & 0.871 & 129 & 0.511 & 130 & 0.735 \\
\hline \multicolumn{9}{|l|}{ Government new regulation $(n=468)$} \\
\hline Symptoms $(n=321)$ & 206 & 0.799 & 361 & 0.326 & 254 & 0.819 & 282 & 0.580 \\
\hline Medicine $(n=98)$ & 141 & 0.505 & 263 & 0.845 & 177 & 0.723 & 180 & 0.093 \\
\hline Comorbid $(n=89)$ & 29 & 0.605 & 57 & 0.969 & 37 & 0.723 & 47 & 0.445 \\
\hline $\operatorname{Vaccine}(\mathrm{n}=97)$ & 32 & 0.224 & 75 & 0.368 & 44 & 0.561 & 52 & 0.942 \\
\hline \multirow[t]{2}{*}{ Local repatriated $($ mudik) $(\mathrm{n}=245)$} & 54 & 0.622 & 88 & 0.832 & 70 & 0.248 & 65 & 0.777 \\
\hline & 67 & 0.113 & 107 & 0.448 & 82 & 0.077 & 94 & $0.007 *$ \\
\hline \multicolumn{9}{|l|}{ Trust in news } \\
\hline Yes & 198 & & 386 & & 253 & & 283 & \\
\hline No & 22 & $0.000^{*}$ & 41 & 0.000 & 31 & $0.000^{*}$ & 88 & $0.000^{*}$ \\
\hline Unsure & 94 & & 129 & & 101 & & 274 & \\
\hline
\end{tabular}

People who were updated to the latest news of COVID-19 felt a significant impact on the mental and emotional health status ( $p$-value <0.05). Television, as one of the news sources, has a significant relationship with depression, anxiety, and emotional disorder on participants ( $p$-value $<0.05$ ). Using social media to look up information of COVID-19 has a big role in the mental health of participants. It is presented that Twitter had a significant association with depression ( $p$-value $<0.05$ ) and emotional disorder ( $p$ value $=0.000$ ), while Facebook, Twitter, and Instagram had a significant association with anxiety and stress (p-value <0.05). The table also showed that friends and family had a significant relationship with stress on participants ( $\mathrm{p}$-value $=0.45$ ). Though only a few participants used radio, a significant association was presented with emotional disorder ( $\mathrm{p}$-value=0.038). Only preventive measurements of COVID-19 information had a significant relationship to all mental and emotional health state while local repatriation (mudik) had a significant relationship only with emotional disorder ( $\mathrm{p}$-value $<0.05$ ). The level of trust of COVID-19 news also has a significant association with the mental and emotional health state of participants

The prevalence of mental and emotional disorders as indicated by symptoms of depression and anxiety reached 14 million people or $6 \%$ of the Indonesia population in 2018 [15]. In this study, out of 1,508 samples, $20.7 \%$ were depressed, $36.9 \%$ had anxiety, $25.5 \%$ had been stress, and $27.6 \%$ had an emotional disorder. These results indicate that there is an increasing prevalence of mental and emotional disorders during the COVID-19 pandemic. This study displayed that news dissemination of COVID-19 was related to emotional and mental health during the COVID-19 pandemic. Amid this condition, the media in Indonesia always tried to provide updated information about the current situation from online news portals, print media, and social media platforms. The increasing COVID-19 cases in Indonesia as well as policies related to the pandemic issued by the government had triggered people's information-seeking behavior regarding their health risks, diseases, and behavior [16]-[17]. Previous research had shown that there was a tendency to increase the trend of community searches related to COVID-19 from various factors [18]-[19].

Searching for news through online news channels was more common while information from television ranked second. It was not surprising as the spread of COVID-19 information from television occurred every day and was in prime time. The rapidly growing digital era caused the dissemination of 
information to be faster and easier, one of which was access to information via the Internet. In line with a survey conducted by the Indonesian Internet Service Providers Association (APJII), out of 143.26 million or $54.68 \%$ of the total population in Indonesia use the Internet service in 2017 and increased to $171.1 \mathrm{million}$ in 2018 [20], [21]. Internet services made it easier for the public to obtain information related to COVID-19 both from social media and search engines. In addition, some people had a habit of using the Internet to read articles $(55.30 \%)$ and to seek health-related information $(51.06 \%)$ [22].

Although news dissemination were mostly sourced on online news channels and WhatsApp, mental and emotional health disorders were related to news dissemination via television, Facebook, Twitter, Instagram, radio, and through friends/family. Facebook, Instagram and Twitter are the most frequently used by Indonesian people when using the internet. Most Indonesians use the internet for social media (51.5\%) and communicate via messages (32.9\%) [21]. This can lead to a high prevalence of mental health disorders due to overexposure to social media [23], [24]. The floods of headlines available about COVID-19, that can access in various media, and continuously reported was filled with the dangers of COVID-19, the increasing number of cases, the scarcity of resources, up to the social and economic that were affected had triggered alertness and excessive concern in the community [25]-[26].

Today, television, online sites, and social media platforms were important in broadcasting information during the outbreak of COVID-19. The Centers for Disease Control and Prevention, WHO, numerous journals, and other health care organizations regularly posted guidance across diverse platforms. Teams employed by larger social media platforms had also been involved as searches for Coronavirus information escalated and, at times, dominating conversations online [27], [28]. Facebook was using the news feed function to direct users to the WHO and local health authorities websites [27]. Google Scholar had highlighted leading medical journals and other sites while Twitter and other social media were similarly routing individuals (accounting for misspellings) to reliable resources related to coronavirus [28]. Health care organizations, clinicians, and social media influencers should also actively direct internet users to trusted sources.

This study showed that the type of news in the form of preventive measures effected on mental health symptoms and emotional disorders. This was in line with previous research where high levels of mental health symptoms were associated with COVID-19 prevention efforts [29], [30]. Information seeking was an attempt to bridge the knowledge gap. In the context of seeking information about health (a preventive measure), a person may not know clearly about a particular health problem that described a knowledge gap about a disease, so there was a need to seek detailed information about the problem [31]. This is in contrast to the theory that stated the information-seeking was carried out to reduce stress and uncertainty in the face of threats (such as health problems) [32]. The news dissemination of local repatriated (mudik) also affects a person's emotional disorder. The prohibition of local repatriated (mudik) lead to restricted social relations and cannot assemble with family, resulting in feelings of loss and loneliness, which potentially worsens individual emotions in situations full of threats, uncertainty and ambiguity such as the COVID-19 pandemic [26].

Social media should be used to spread reliable information on preventive measures, when to get tested, what to do with the results, and where to receive care. If a vaccine becomes available, the same platforms could be used to encourage uptake and address challenges associated with vaccine hesitancy. Health systems may become overwhelmed as testing becomes more available and as more mildly ill yet concerned individuals seek care, social media platforms are well poised to enable users to remotely assess symptoms and determine their most appropriate course of action using telemedicine [33], [34]. However, social media such as Facebook, Twitter, YouTube, and WhatsApp has also become a conduit for spreading both rumours and deliberate misinformation that many perpetrators are deploying to create a sense of panic and confusion [33]. Dissemination of health-related fake news can endanger someone's safety because lured to take the wrong precautions [35].

During the COVID-19 outbreak, mental health burden was identified. Younger people spent too much time thinking and searching about the outbreak while healthcare workers were at high risk of mental illness. If this continues, the community will fall into mental disorders in the future. Controlling and limiting the time to obtain COVID-19 related news within two hours a day, focus only on the necessary information such as facts and data and avoid receiving too many harmful rumours could be implemented to deal with this pandemic [36]. Continuous surveillance of the psychological consequences due to outbreaks should be a routine as a part of worldwide vigilance. Psychological first aid could be delivered through chatbots equipped with artificial intelligence in response to the pandemic and better understand critical needs. While social media cannot replace in-person contact, there may be ways to use it to support recovery and resilience, so people will have an idea about their health and have the right protection [37].

This study had several limitations. The study was limited to the COVID-19 outbreak where an online questionnaire was used to avoid possible infections thus sampling in the study was voluntary and 
conducted by an online system. Therefore, the possibility of selection bias should be considered. Furthermore, writers were unable to assess the individual's psychological conditions of the respondents before the outbreak due to the sudden occurrence of the disaster.

\section{CONCLUSION}

News dissemination of COVID-19 affects the emotional and mental health status of Indonesian society. Latest news, news sources such as television and social media, type of news, and level of trust in COVID-19 news were the ones that influenced it. Indonesian government should provide appropriate tailored mental health support through hotline teams, media, or multidisciplinary teams, including mental health professionals to help Indonesian society through this pandemic.

\section{REFERENCES}

[1] V. Surveillances, "The epidemiological characteristics of an outbreak of 2019 novel coronavirus diseases (COVID19) - China, 2020," China CDC Wkly., vol. 2, no. 8, pp. 113-122, 2020.

[2] N. Chen et al., "Epidemiological and clinical characteristics of 99 cases of 2019 novel coronavirus pneumonia in Wuhan, China: a descriptive study," Lancet, vol. 395, no. 10223, pp. 507-513, 2020, doi: 10.1016/S01406736(20)30211-7.

[3] WHO Regional Office for Europe, "2019-nCoV outbreak is an emergency of international concern," 2020, [Online]. Available: https://www.euro.who.int/en/health-topics/health-emergencies/international-healthregulations/news/news/2020/2/2019-ncov-outbreak-is-an-emergency-of-international-concern (accessed Jun. 07, 2020).

[4] WHO, "Coronavirus disease (COVID-19) Situation Report-138," 2020, [Online]. Available: https://www.who.int/publications/m/item/situation-report---138.

[5] Infeksi Emerging, "Coronavirus Disease (COVID-19) Update 6 June 2020 (In Indonesia: Situasi Terkini Perkembangan Coronavirus Disease (COVID-19) 6 Juni 2020)," Kementerian Kesehatan RI, 2020, [Online]. Available: https://infeksiemerging.kemkes.go.id/situasi-infeksi-emerging/situasi-terkini-perkembangancoronavirus-disease-covid-19-6-juni-2020 (accessed Jun. 07, 2020).

[6] WHO, "Managing epidemics: key facts about major deadly diseases," Geneva, Switzerland: World Health Organization, 2018.

[7] WHO, "Coronavirus disease 2019 (COVID-19) Situation Report-13," 2020, [Online]. Available: chromeextension://efaidnbmnnnibpcajpcglclefindmkaj/viewer.html?pdfurl=https\%3A\%2F\%2Fwww.who.int\%2Fdocs\%2F default-source\%2Fsearo\%2Findonesia\%2Fcovid $19 \% 2$ Fexternal-situation-report-1325june2020.pdf\%3Fsfvrsn\%3D40029af0_6\&clen=1869453\&chunk=true.

[8] Y. Xiang et al., "Timely mental health care for the 2019 novel coronavirus outbreak is urgently needed," The Lancet Psychiatry, vol. 7, no. 3, pp. 228-229, 2020, doi: 10.1016/S2215-0366(20)30046-8.

[9] C. S. H. Ho, C. Y. I. Chee, M. Psychiatry, and R. C. M. Ho, "Mental Health Strategies to Combat the Psychological Impact of COVID-19 Beyond Paranoia and Panic," Ann. Acad. Med. Singapore, vol. 49, no. 1, pp. 1-6, 2020.

[10] C. Wang et al., "Immediate Psychological Responses and Associated Factors during the Initial Stage of the 2019 Coronavirus Disease ( COVID-19) Epidemic among the General Population in China," Int. J. Environ. Res. Public Health, vol. 17, no. 5, pp. 1-25, 2019, doi: 10.3390/ijerph17051729.

[11] T. Van Bortel et al., "Psychosocial effects of an Ebola outbreak at individual , community and international levels," Bull. World Health Organ., vol. 94, no. 3, pp. 210-214, 2016, doi: 10.2471/BLT.15.158543.

[12] I. Solomou and F. Constantinidou, "Prevalence and Predictors of Anxiety and Depression Symptoms during the COVID-19 Pandemic and Compliance with Precautionary Measures : Age and Sex Matter," Int. J. Environ. Res. Public Health, vol. 17, no. 14, p. 4924, 2020, doi: 10.3390/ijerph17144924.

[13] S. Idaiani and A. Y. Kristanto, "Analisis Gejala Gangguan Mental Emosional Penduduk Indonesia," Major. Kedokt. Indones., vol. 59, pp. 473-479, 2007.

[14] I. Ganihartono, "Psychiatric morbidity among patients attending the Bangetayu community health centre in Indonesia," Buletin Penelitian Kesehatan, vol. 24, no. 4, pp. 42-51, 1996.

[15] Y. A. Indrayani and T. Wahudi, "Mental health situation in Indonesia. Data and Information Center of the Indonesian Ministry of Health," Winne Widi. Jakarta: Pusat Data dan Informasi KEMENKES RI, 2019.

[16] M. F. Rizqullah and R. A. Syakurah, "Analysis of public search interest regarding government containment policy on COVID-19 new cases in Indonesia, Malaysia and Singapore," Health Promotion Perspectives, vol. 11, no. 3, pp. 360-368, 2021, doi: 10.34172/hpp.2021.xx.

[17] W. Jacobs, A. O. Amuta, and K. C. Jeon, "Health information seeking in the digital age: An analysis of health information seeking behavior among US adults Health information seeking in the digital age: An analysis of health information seeking behavior among US adults," Cogent Soc. Sci., vol. 11, no. 1, pp. 1-11, 2017, doi: $10.1080 / 23311886.2017 .1302785$.

[18] A. Mills and N. Todorova, "An integrated perspective on factors influencing online health-information seeking behaviours. Australasian Conference on Information Systems, 4, 6.," in 27th Australasian Conference on Information Systems (ACIS 2016), 2016, p. 83.

[19] N. Mahfuza, R. A. Syakurah, and R. Citra, "Analysis and potential use of google trends as a monitoring tool for 
risk communication during COVID-19 pandemic," International Journal Public Health Science (IJPHS), vol. 9, no. 4, pp. 399-405, 2020, doi: 10.11591/ijphs.v9i4.20512.

[20] M. Chandra and R. Syakurah, "Potential use of personal protection online search during COVID-19 pandemic for predicting and monitoring public response," International Journal Public Health Science (IJPHS), vol. 9, no. 4, pp. 406-413, 2020, doi: 10.11591/ijphs.v9i4.20547.

[21] L. Amelia and R. A. Syakurah, "Analysis of public search interest towards immune system improvement during the COVID-19 pandemic using google trends," International Journal Public Health Science (IJPHS), vol. 9, no. 4, pp. 414-420, 2020, doi: 10.11591/ijphs.v9i4.20518.

[22] R. Imansyah, "Impact of internet penetration for the economic growth of Indonesia," Evergreen, vol. 5, no. 2, pp. 36-43, 2018, doi: 10.5109/1936215.

[23] Association of Indonesian Internet Service Providers, "Internet Survey Report Indonesian Internet Service Providers Association (APJII) 2019-2020 (Q2)," Jakarta Selatan, 2020. [Online]. Available: https://apjii.or.id/content/read/39/521/Laporan-Survei-Internet-APJII-2019-2020-Q2.

[24] Association of Indonesian Internet Service Providers (APJII), "Indonesian Internet User Penetration \& Behavior Survey 2017," Jakarta, 2017, [Online]. Available: https://apjii.or.id/content/read/39/342/Hasil-Survei-Penetrasidan-Perilaku-Pengguna-Internet-Indonesia-2017.

[25] J. Gao et al., "Mental health problems and social media exposure during COVID-19 outbreak," PLoS One, vol. 15, no. 4, p. e0231924, 2020, doi: 10.1371/journal.pone.0231924.

[26] D. R. Garfin, R. C. Silver, and E. A. Holman, "The Novel Coronavirus (COVID-2019) Outbreak : Amplification of Public Health Consequences by Media Exposure,” Heal. Psychol., vol. 39, no. 5, pp. 355-357, 2020, doi: 10.1037/hea0000875.

[27] R. Rosita, "International journal of multi science panic buying in the covid - 19 pandemic era in indonesia," Int. J. Multi Sci., vol. 1, no. 6, pp. 60-70, 2020.

[28] World Health Organization, "Mental health and psychosocial considerations during the COVID-19 outbreak, 18 March 2020," Geneva, 2020. [Online]. Available: https://apps.who.int/iris/handle/10665/331490?localeattribute $=$ ar\&locale- $=$. (accessed Jun. 07, 2020).

[29] D. Christanti and M. Yuliastuti, "The Effect of Anxiety towards the Perception of COVID-19 Information Mediated by Reflective Thinking Skills," Nusantara Journal of Social Sciences and Humanities, vol. 1, no. 1, pp. $158-171,2020$.

[30] E.O. Nsoesie and O. Oladeji, "Identifying patterns to prevent the spread of misinformation during epidemics," Harvard Kennedy School (HKS) Misinformation Review, vol. 1, no. 3, 2020, doi: 10.37016/mr-2020-014.

[31] S. Khalifa et al., "Beyond the Pandemic: COVID-19 Pandemic Changed the Face of Life," International Journal of Environmental Research and Public Health, vol. 18, no. 11, pp. 1-20, doi: 10.3390/ijerph18115645.

[32] L. P. Wong, C. Hung, H. Alias, and T. S. Lee, "Anxiety symptoms and preventive measures during the COVID-19 outbreak in Taiwan," BMC Psychiatry, vol. 20, no. 1, pp. 1-9, 2020, doi: 10.1186/s12888-020-02786-8.

[33] Y. Pan, M. Xin, C. Zhang, W. Dong, and Y. Fang, "Associations of Mental Health and Personal Preventive Measure Compliance With Exposure to COVID-19 Information During Work Resumption Following the COVID-19 Outbreak in China : Cross-Sectional Survey Study," J. Med. Internet Res., vol. 22, no. 10, pp. 1-17, 2020, doi: 10.2196/22596.

[34] L. M. S. Miller and R. A. Bell, "Online health information seeking: The influence of age, information trustworthiness, and search challenges," J. Aging Health, vol. 24, no. 3, pp. 525-541, 2012, doi: $10.1177 / 0898264311428167$.

[35] D. Potnis, “Wilson's information-seeking behavior models (1981, 1996, 1999)," In Information Seeking Behavior And Technology Adoption: Theories And Trends, IGI Global, pp. 94-112, 2015.

[36] R. M. Merchant, "Evaluating the potential role of social media in preventive health care," JAMA, vol. 323, no. 5, pp. 411-412, 2020, doi: 10.1001/jama.2019.21084.

[37] N. M. Lacktman, D. L. Rosen, M. R. Chmielewski, and N. A. Beaver, "2017 Telemedicine and Digital Health Survey," 2017, [Online]. Available: https://www.foley.com/en/insights/publications/2017/11/2017-telemedicine-digital-health-survey.

[38] C. M. Pulido, B. Villarejo-Carballido, G. Redondo-Sama, and A. Gómez, "COVID-19 infodemic: More retweets for science-based information on coronavirus than for false information," Int. Sociol., vol. 35, no. 4, pp. 377-392, 2020, doi: 10.1177/0268580920914755.

[39] Y. Huang and N. Zhao, "Generalized anxiety disorder, depressive symptoms and sleep quality during COVID-19 outbreak in China: a web-based cross-sectional survey," Psychiatry Res., vol. 288, no. June, pp. 1-6, 2020, doi: 10.1016/j.psychres.2020.112954.

[40] S. Divya, V. Indumathi, S. Ishwarya, M. Priyasankari, and S. K. Devi, "A self-diagnosis medical chatbot using artificial intelligence,” J. Web Dev. Web Des., vol. 3, no. 1, pp. 1-7, 2018. 